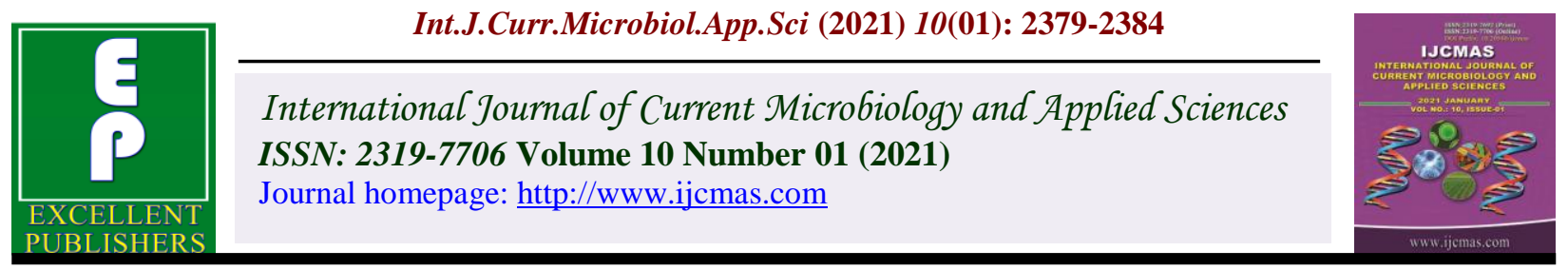

Original Research Article

https://doi.org/10.20546/ijcmas.2021.1001.276

\title{
Epidemiological Studies of Leaf Spot of Pigeonpea [Cajanus cajan (L.) Millsp.] Caused by Cercospora cajani
}

\author{
Vijay Kumar Kashyap, A. K. Choudhary and Vivek Kumar Vishwakarma* \\ Department of Plant Pathology, RVSKVV College of Agriculture, \\ Sehore (M.P.) 466001, India \\ *Corresponding author
}

\begin{tabular}{|l|}
\hline K e y w o r d s \\
Leaf Spot of \\
Pigeonpea \\
[Cajanus cajan] \\
Cercospora cajani \\
\hline Article Info \\
\hline $\begin{array}{l}\text { Accepted: } \\
\text { 15 December } 2020 \\
\text { Available Online: } \\
\text { 10 January 2021 }\end{array}$ \\
\hline
\end{tabular}

A B S T R A C T

Cercospora leaf spot caused by Cercospora cajani Henningsis one of the most important fungal diseases of Pigeon pea [Cajanus cajan (L.) Millsp.]. Epidemiology of Cercospora cajani of pigeon pea. The correlation studies between individual parameters and CLS intensity was carried out and the data are summarized in which reveals that maximum temperature (0.06089) showed correlation coefficient with the disease intensity. This non significant and negative correlation indicates that the disease incidence increased with decrease in maximum temperature. On the other hand minimum temperature $(-0.86547 *)$, average maximum relative humidity ($\left.0.82866^{*}\right)$, total rainfall $\left(-0.75349^{*}\right)$ and number of total rainy days ($0.79524 *)$ showed negative correlation coefficient with the disease intensity which clearly indicates that the disease increased with the decrease in average relative humidity, average minimum relative humidity, total rainfall.

\section{Introduction}

Pigeonpea [Cajanus cajan (L.) Millsp.] is an important grain legume crop of rainfed agriculture in the semi-arid tropics. Besides Indian sub-continent, it is widely grown in Eastern Africa and Central America. It is not only an important source of protein, but also plays an important role in atmospheric nitrogen fixation into soil (Reddy et al., 2012). Globally pigeon pea is cultivated in about on 4.7 million ha area with 3.69 million tonnes annual production. India accounts $78 \%$ of the global output with current production of 2.78 million tonnes from 3.5 million ha. In Madhya Pradesh Pigeon pea is grown in about 0.57 million ha with an annual production of 0.57 million tonnes. The average yield of Pigeon pea in M.P. is $848 \mathrm{~kg} / \mathrm{ha}$ which is much larger than the potential yield of crop (1500-2000 kg/ha). Several biotic and abiotic factors are responsible for reducing the yield 
(Anno. 2018). Cercospora leaf spot inflicts heavy yield losses ranging from 23 to 96 per cent under natural epiphytotic conditions. (Kasno, 1990; Iqbal et al., 1995; Kaur, 2007). The yield losses vary depending upon how early the crop is infected in the season, crop variety and prevailing weather. The leaf spot disease is caused by fungus Cercospora cajani. It is present in parts of Uttar Pradesh, Bihar and several places of south India (Reddy et al., 2012).

\section{Materials and Methods}

\section{Experimental site}

The field experiments were conducted during kharif 2018 at the experimental field of Department of Plant Pathology, R.A.K. College of Agriculture, Sehore (M.P.).

\section{Epidemiology}

The weekly weather data for the period of the observations i.e. July to December 2018. The meteorological parameters data on temperature, relative humidity $(\mathrm{RH})$, rainfall and number of rainy days were also recorded separately at weekly interval during crop season in year 2018-19 from the Meteorological Department of College of Agriculture, sehore (Table-1). After emergence 10 plants from each plot were randomly selected tagged and inoculated with conidial suspension of Cercospora cajani. The inoculated plants were covered by polythene bags for three days. The initiation and progress of the disease was recorded on tagged plants at weekly interval starting from the first appearance of the symptoms. Simultaneously the meteorological parameters viz., temp. (Max and Min.), RH (Max. and Min.), number of rainy days will also were recorded and their after a correlation study was made to find out the role of individual meteorological parameter on the development of the disease. The linear relationship of disease development with environmental factors was calculated by Karl Pearson linear correlation coefficient. The quantity $r$, called the linear correlation coefficient, measures the strength and the direction of a linear relationship between two variables. The linear correlation coefficient is sometimes referred to as the Pearson product moment correlation coefficient in honor of its developer Karl Pearson.

The mathematical formula for computing $r$ is:

$$
r=\frac{n \sum x y-\left(\sum x\right)\left(\sum y\right)}{\sqrt{n\left(\sum x^{2}\right)-\left(\sum x\right)^{2}} \sqrt{n\left(\sum y^{2}\right)-\left(\sum y\right)^{2}}}
$$

Where, $n$ is the number of pairs of data.

Based on disease incidence the lines were categorized as per the scale described by Reddy and Jain (1989) where-

\section{Results and Discussion}

\section{Epidemiology of Cercospora cajani of pigeon pea}

The correlation studies between individual parameters and Cercospora leaf spot intensity was carried out and the data are summarized in (table-3) which reveals that maximum temperature (-0.06089) showed correlation coefficient with the disease intensity. This non significant and negative correlation indicates that the disease incidence increased with decrease in maximum temperature. On the other hand minimum temperature ($0.86547 *)$ average maximum relative humidity $\left(-0.82866^{*}\right)$, total rainfall ($\left.0.75349^{*}\right)$ and number of total rainy days ($\left.0.79524^{*}\right)$ showed negative correlation coefficient with the disease intensity which clearly indicates that the disease increased with the decrease in average relative humidity, average minimum relative humidity, total rainfall. (Table-3 and table-4). 
Maximum temperature showed negative correlation, disease increased with the decrease in maximum temperature. On the other hand minimum temperature, average relative humidity, total rainfall and number of total rainy days showed negative correlation which indicated that the disease increased with the decrease in that parameters.

Earlier, Windels et al., 1998 also worked on different date sowing against Cercospora $s p$. 90-100\% relative humidity for production of conidia and $20-26^{\circ} \mathrm{C}$ temperature. For germination and to cause the infection the ideal temperature recorded is $25-30^{\circ} \mathrm{C}$. If the temperature is below than $10^{\circ} \mathrm{C}$ then no conidia are formed (Windels et al., 1998). Wallin \& Loonan (1971) reported an increase in leaf spots in the order of 30 to 80 times after periods of 48 or $72 \mathrm{~h}$ leaf wetness, respectively, compared to a leaf wetness period of $24 \mathrm{~h}$. Optimal temperatures between $22-28^{\circ} \mathrm{C}$ are reported for these pathogens during infection of their respective hosts.

Table.1 Meterological parameters

\begin{tabular}{|c|c|c|c|c|c|c|}
\hline Date & $\begin{array}{c}\text { Standard } \\
\text { week }\end{array}$ & $\begin{array}{c}\text { Temp } \\
\left(\text { Max. }^{\circ} \mathrm{C}\right)\end{array}$ & $\begin{array}{c}\text { Temp. } \\
\left(\text { Min. }{ }^{\circ} \text { C) }\right.\end{array}$ & $\begin{array}{c}\text { Relative } \\
\text { humidity }(\%)\end{array}$ & $\begin{array}{c}\text { Rainfall } \\
(\mathbf{m m})\end{array}$ & $\begin{array}{l}\text { Number of } \\
\text { rainy days }\end{array}$ \\
\hline 9-15 July & 28 & 29.64 & 23.94 & 89.36 & 280.00 & 5 \\
\hline 16-22 July & 29 & 28.36 & 24.39 & 91.43 & 268.50 & 4 \\
\hline 23-29 July & 30 & 26.44 & 23.56 & 93.5 & 71.00 & 2 \\
\hline 30-5 Aug & 31 & 30.04 & 24.50 & 81.07 & 0.00 & - \\
\hline 6-12 Aug. & 32 & 28.24 & 23.76 & 81.9 & 19.00 & 1 \\
\hline 13-19 Aug & 33 & 28.86 & 23.99 & 92.64 & 132.00 & 3 \\
\hline 20-26 Aug & 34 & 26.53 & 23.00 & 97.71 & 100.10 & 2 \\
\hline 27-2 Sept. & 35 & 26.34 & 22.44 & 94.36 & 4.90 & 1 \\
\hline 3-9 Sept & 36 & 24.94 & 20.91 & 79.71 & 33.50 & 1 \\
\hline 10-16 Sept & 37 & 29.67 & 20.56 & 75.50 & 8.60 & 1 \\
\hline 17-23 Sept & 38 & 31.57 & 21.61 & 71.14 & 41.00 & 1 \\
\hline 24-30 Sept. & 39 & 33.50 & 20.66 & 64.79 & 2.00 & 1 \\
\hline 1-7 Oct & 40 & 34.46 & 20.06 & 58.79 & 19.50 & 1 \\
\hline 8-14 Oct. & 41 & 34.46 & 18.10 & 56.00 & 0.00 & - \\
\hline 15-21 Oct & 42 & 34.03 & 19.17 & 45.50 & 0.00 & - \\
\hline 22-28 Oct. & 43 & 33.10 & 15.70 & 42.6 & 0.00 & - \\
\hline 29Oct-4 Nov. & 44 & 30.74 & 16.07 & 53.8 & 0.00 & - \\
\hline 5-11 Nov. & 45 & 30.14 & 12.66 & 45.9 & 0.00 & - \\
\hline 12-18 Nov. & 46 & 30.07 & 13.24 & 45.4 & 0.00 & - \\
\hline 19-25Nov. & 47 & 29.87 & 15.61 & 47.6 & 0.00 & - \\
\hline 26Nov-2Dec & 48 & 26.40 & 11.69 & 58.9 & 0.00 & - \\
\hline 03-09Dec & 49 & 24.66 & 12.71 & 53.7 & 0.00 & - \\
\hline 10-16 Dec. & 50 & 22.83 & 9.79 & 59.1 & 0.00 & - \\
\hline 17-23 Dec. & 51 & 22.91 & 4.86 & 55.0 & 0.00 & - \\
\hline
\end{tabular}

Based on disease incidence the lines were categorized as per the scale described by Reddy and Jain (1989) where- 
Table.2 Disease rating scale

\begin{tabular}{|c|c|c|c|}
\hline $\begin{array}{l}\text { Disease } \\
\text { grade }\end{array}$ & Description & $\begin{array}{c}\text { Disease } \\
\text { grade }\end{array}$ & $\begin{array}{l}\text { Disease } \\
\text { reaction }\end{array}$ \\
\hline $\mathbf{0}$ & No symptom & $0-1$ & Immune \\
\hline 1 & Lesion small pin head covering less than $1 \%$ leaf & $1.1-3$ & Resistant \\
\hline 3 & Lesion $1-2 \mathrm{~mm}$ diameter covering $1-10 \%$ leaf area & $3.1-5$ & $\begin{array}{l}\text { Moderately } \\
\text { Resistant }\end{array}$ \\
\hline 5 & Enlarged lesion with $11-25 \%$ leaf coverage & $5.1-7$ & $\begin{array}{l}\text { Moderately } \\
\text { Susceptible }\end{array}$ \\
\hline 7 & Lesion covering $26-50 \%$ of the leaf area & $7.1-9$ & Susceptible \\
\hline 9 & $\begin{array}{l}\text { More than } 50 \% \text { of the area covered by large coalescing } \\
\text { lesion and defoliation }\end{array}$ & & $\begin{array}{l}\text { Highly } \\
\text { Susceptible }\end{array}$ \\
\hline
\end{tabular}

Table.3 Weather and disease progress during year 2018-19 at Sehore date of sowing $8^{\text {th }}$ July 2018

\begin{tabular}{|c|c|c|c|c|c|c|c|}
\hline Date & $\begin{array}{c}\text { Standard } \\
\text { week }\end{array}$ & $\begin{array}{c}\text { Temp } \\
\left(\mathbf{M a x}{ }^{\circ} \mathbf{C}\right)\end{array}$ & $\begin{array}{c}\text { Temp. } \\
\left(\text { Min }^{\circ} \mathbf{C}\right)\end{array}$ & $\begin{array}{c}\text { Relative } \\
\text { humidity }(\boldsymbol{\%})\end{array}$ & $\begin{array}{c}\text { Rainfall } \\
(\mathbf{m m})\end{array}$ & $\begin{array}{c}\text { Number of } \\
\text { rainy days }\end{array}$ & $\begin{array}{c}\text { Progress of } \\
\text { disease }(\mathbf{\%})\end{array}$ \\
\hline 9-15 July & 28 & 29.64 & 23.94 & 89.36 & 280.00 & 6 & 5.5 \\
\hline 16-22 July & 29 & 28.36 & 24.39 & 91.43 & 268.50 & 6 & $11.55(6.05)$ \\
\hline 23-29 July & 30 & 26.44 & 23.56 & 93.5 & 71.00 & 5 & $18.31(6.76)$ \\
\hline 30-5 Aug & 31 & 30.04 & 24.50 & 81.07 & 0.00 & 0 & $20.1(1.79)$ \\
\hline 6-12 Aug. & 32 & 28.24 & 23.76 & 81.9 & 19.00 & 3 & $22.4(2.3)$ \\
\hline 13-19 Aug & 33 & 28.86 & 23.99 & 92.64 & 132.00 & 6 & $26.4(4.0)$ \\
\hline 20-26 Aug & 34 & 26.53 & 23.00 & 97.71 & 100.10 & 6 & $34.4(8.00)$ \\
\hline 27-2 Sept. & 35 & 26.34 & 22.44 & 94.36 & 4.90 & 2 & $37.3(2.9)$ \\
\hline 3-9 Sept & 36 & 24.94 & 20.91 & 79.71 & 33.50 & 4 & $38(0.7)$ \\
\hline 10-16 Sept & 37 & 29.67 & 20.56 & 75.50 & 8.60 & 3 & $39.11(1.11)$ \\
\hline 17-23 Sept & 38 & 31.57 & 21.61 & 71.14 & 41.00 & 2 & $40.2(1.09)$ \\
\hline 24-30 Sept. & 39 & 33.50 & 20.66 & 64.79 & 2.00 & 1 & $41.11(0.91)$ \\
\hline 1-7 Oct & 40 & 34.46 & 20.06 & 58.79 & 19.50 & 0 & $43.44(2.33)$ \\
\hline 8-14 Oct. & 41 & 34.46 & 18.10 & 56.00 & 0.00 & 0 & $46.12(2.68)$ \\
\hline 15-21 Oct & 42 & 34.03 & 19.17 & 45.50 & 0.00 & 0 & $49.0(2.88)$ \\
\hline 22-28 Oct. & 43 & 33.10 & 15.70 & 42.6 & 0.00 & 0 & $51.5(2.5)$ \\
\hline 29Oct-4 Nov. & 44 & 30.74 & 16.07 & 53.8 & 0.00 & 0 & $54.55(3.05)$ \\
\hline 5-11 Nov. & 45 & 30.14 & 12.66 & 45.9 & 0.00 & 0 & $54.75(0.20)$ \\
\hline 12-18 Nov. & 46 & 30.07 & 13.24 & 45.4 & 0.00 & 0 & $55.12(0.37)$ \\
\hline 19-25Nov. & 47 & 29.87 & 15.61 & 47.6 & 0.00 & 0 & $55.78(0.66)$ \\
\hline 26Nov-02Dec & 48 & 26.40 & 11.69 & 58.9 & 0.00 & 0 & $58.12(2.34)$ \\
\hline 03- 09Dec & 49 & 24.66 & 12.71 & 53.7 & 0.00 & 0 & $58.78(0.66)$ \\
\hline 10-16 Dec. & 50 & 22.83 & 9.79 & 59.1 & 0.00 & 0 & $59.00(0.44)$ \\
\hline 17-23 Dec. & 51 & 22.91 & 4.86 & 55.0 & 0.00 & 0 & $61.00(2.88)$ \\
\hline
\end{tabular}

(*Figures in parentheses are arcsine transformed values) 
Table.4 Correlation coefficient of individual meteorological parameters with progressive development of Cercospora leaf spot of Pigeon pea

\begin{tabular}{|c|c|c|}
\hline S.No & Weather Parameters & Correlation coefficient \\
\hline $\mathbf{1}$ & Maximum temperature & -0.06089 \\
\hline $\mathbf{2}$ & Minimum temperature & $-0.86547^{*}$ \\
\hline $\mathbf{3}$ & Relative humidity \% & $-0.82866^{*}$ \\
\hline $\mathbf{4}$ & Rainfall (mm) & $-0.75349^{*}$ \\
\hline $\mathbf{5}$ & Total rainy days & $-0.79524^{*}$ \\
\hline
\end{tabular}

R-square value (0.754), * Significant at 5\%

Fig.1 Weather and disease progress during year 2018-19, at Sehore.

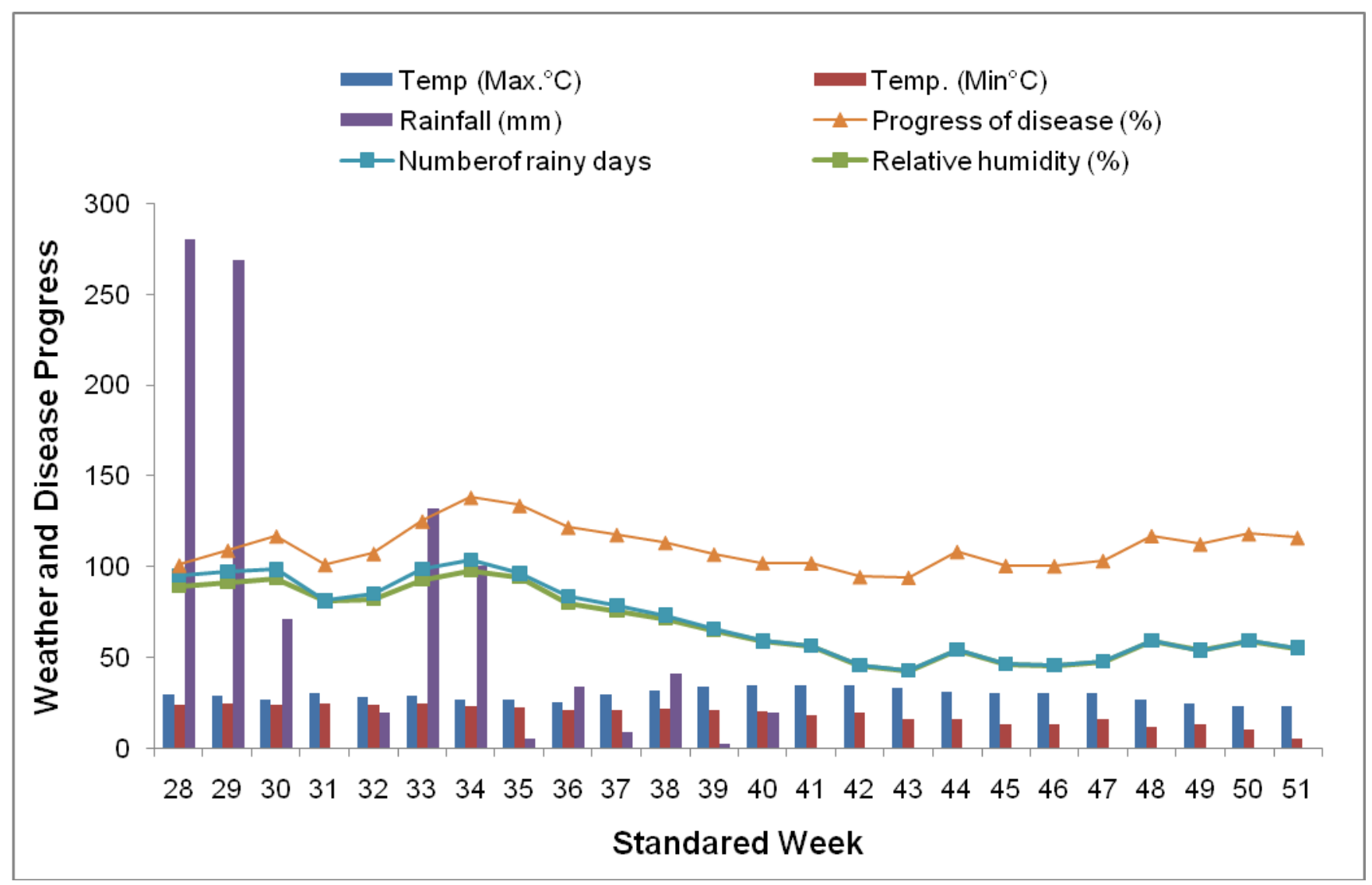

\section{References}

Anonymous, 2018. Annual Report of AICRP on pigeon pea, pp: 192-193.

Iqbal, S.M., Ghafoor, A., Basak, M. and Malik, B.A.(1995). Estimation of losses in yield components of mungbean due to cercospora leaf spot. Pak J Phytopath. 7: 80-81
Kasno, A. 1990. The tolerance of mungben genotypes to Cercospora leaf spot. Penel Palawi. 5: 39-47.

Kaur, L. 2007. Multiple disease resistant sources of mungbean. Act Hort. 752: 423-426.

Reddy, M. V. and Jain, K. C. 1989. Recent advances in breeding for disease resistance in Pigeonpea. In: New 
Frontiers in Pulses Research and Development: Proceedings of National Symposium. ICRISAT, Patancheru, India.

Reddy, M.V.; Raju, T.N.; Sharma,S. B. ; Nene,Y. L.; McDonald, D. ; Pande, P. and Sharma, M. 2012. Handbook of Pigeonpea Disease, Information Bulletin No 42 (Revised, 2012) (ICRISAT), Patancheru $502 \quad 324$ Andhra Pradesh, India, pp. 22-23.
Wallin J.R. and Loonan D.V., (1971). Effect of leaf wetness duration and air temperature on Cercospora beticola infection of sugarbeet. Phytopathology 61, 546-549.

Windels, C. E., Lamay, H. A. , Hilde, D., Winder, J. and Knudsen, T. 1998. A Cercospora leaf spot model for sugar beet. Plant Diseases, 82:716-726.

\section{How to cite this article:}

Vijay Kumar Kashyap, A. K. Choudhary and Vivek Kumar Vishwakarma. 2021. Epidemiological Studies of Leaf Spot of Pigeonpea [Cajanus cajan (L.) Millsp.] Caused by Cercospora cajani. Int.J.Curr.Microbiol.App.Sci. 10(01): 2379-2384.

doi: https://doi.org/10.20546/ijcmas.2021.1001.276 